\title{
Karakteristik Penderita Epilepsi di Bangsal Anak RSUP Dr. M. Djamil Padang Tahun 2018
}

\author{
Khairin, $\mathrm{K}^{1}$, Zeffira, $\mathrm{L}^{2}$, Malik, $\mathrm{R}^{3}$ \\ ${ }^{1}$ Mahasiswa Fakultas Kedokteran Universitas Baiturrahmah \\ e-mail: viaa0321@gmail.com \\ ${ }^{2}$ Bagian Ilmu Kesehatan Anak, Fakultas Kedokteran Universitas Baiturrahmah Padang, Indonesia \\ e-mail: laurazeffira@fk.unbrah.ac.id \\ ${ }^{3}$ Bagian Biokimia, Fakultas Kedokteran Universitas Baiturrahmah Padang, Indonesia \\ e-mail: rifkindmalik@fk.unbrah.ac.id
}

\begin{abstract}
Abstrak
Latar Belakang: Epilepsi merupakan suatu keadaan yang ditandai adanya bangkitan yang terjadi secara berulang akibat terganggunya fungsi otak yang disebabkan oleh muatan listrik yang abnormal pada neuronneuron otak. Epilepsi memiliki dua kategori kejang yaitu kejang fokal dan kejang umum. Insiden epilepsi diperkirakan lebih banyak terdapat pada negara berkembang daripada negara maju. Pada tahun 2017, jumlah kasus epilepsi anak di Sumatera Barat terutama di RSUP Dr. M. Djamil Padang ada 1081 kasus pada rawat jalan dan satu kasus rawat inap dan diperkirakan akan terus meningkat setiap tahunnya. Tujuan: Untuk mengetahui karakteristik penderita epilepsi di bangsal anak RSUP Dr. M. Djamil Padang tahun 2018. Metode: Penelitian ini dilakukan di RSUP Dr. M. Djamil Padang. Penelitian ini bersifat deskriptif dengan rancangan cross sectional. Sumber data dari data sekunder yang berasal dari rekam medis. Sampel dipilih dengan menggunakan kriteria inklusi dan eksklusi. Analisis data menggunakan analisis univariat. Hasil: Didapatkan dari 65 sampel yang menderita epilepsi yaitu usia 0-5 tahun sebanyak 37 orang (56,9\%), jenis kelamin laki-laki sebanyak 39 orang (60\%), tidak memiliki riwayat epilepsi keluarga sebanyak 62 orang $(95,4 \%)$, gambaran EEG gelombang sharp wave dan spike sebanyak 30 orang $(46,2 \%)$, tipe kejang generalized sebanyak 57 orang $(87,7 \%)$ dan asam valproat sebagai salah satu penatalaksanaan epilepsi sebanyak 32 orang (49,2\%). Kesimpulan: Dari hasil penelitian ini, dapat disimpulkan bahwa penderita epilepsi terbanyak adalah usia 0-5 tahun dengan jenis kelamin laki-laki serta tidak memiliki riwayat epilepsi dalam keluarga. Tipe gambaran EEG yaitu gelombang sharp wave dan spike, tipe kejang umum dengan penatalaksanaan terbanyak asam valproat.
\end{abstract}

Kata Kunci : Epilepsi anak, karakteristik, gambaran EEG

\begin{abstract}
Background: Epilepsy is a condition characterized by recurrent seizures that occur due to the disruption of brain function caused by an abnormal electrical charge on brain neurons. Epilepsy has two categories of seizures, they are focal seizures and generalized seizures. The incidence of epilepsy is estimated to be more prevalent in developing countries than developed countries. In 2017, the number of cases of children with epilepsy in West Sumatra, especially at RSUP Dr. M. Djamil Padang, there are 1081 cases in the outpatient and inpatient cases and will be expected to increase every year. Objective: To find out the characteristics of epilepsy disease in the children's ward RSUP Dr. M. Djamil Padang in 2018. Method: This research was conducted at RSUP Dr. M. Djamil Padang. This research is descriptive with cross sectional design. Data sources from secondary data derived from medical records. Samples were selected using inclusion and exclusion criteria. Data analysis uses univariate analysis. Results: The results of the study were obtained from 65 samples suffering from epilepsy, there are age 0-5 years as many as 37 people (56.9\%), male gender as many as 39 people (60\%), do not have a family history of epilepsy as much as 62 people (95.4\%), picture of sharp wave and spikes EEG as many as 30 people (46.2\%), generalized seizure type as many as 57 people (87.7\%) and valproic acid as one of the management of epilepsy as many as 32 people (49,2\%). Conclusion : From the results of this study, it can be concluded that most people with epilepsy are aged 0-5 years with male sex and do not have a
\end{abstract}

Email : heme@unbrah.ac.id 
Heme, Vol II No 2

July 2020

family history of epilepsy. The types of EEG images are sharp waves and spikes, the type of generalized seizures with the most management of valproic acid.

Keywords: Epilepsy in children, characteristics, EEG overview 


\section{Pendahuluan}

Epilepsi berasal dari kata Yunani yaitu epilapsia yang berarti serangan. Epilepsi merupakan suatu keadaan yang ditandai adanya bangkitan yang terjadi secara berulang akibat terganggunya fungsi otak yang disebabkan oleh muatan listrik yang abnormal pada neuron-neuron otak. ${ }^{1}$

Epilepsi adalah salah satu kondisi tertua yang diakui di dunia, dengan catatan tertulis yang berasal dari 4000 SM. Ketakutan, kesalahpahaman, diskriminasi dan stigma sosial telah mengelilingi epilepsi selama berabad-abad. Stigma ini berlanjut di banyak negara dan dapat berdampak pada kualitas hidup orang dengan penyakit dan keluarga mereka. $^{2}$

Epilepsi merupakan manifestasi gangguan fungsi otak dengan berbagai etiologi dan dengan gejala tunggal yang khas, yaitu kejang berulang akibat lepasnya muatan listrik neuron otak secara berlebihan dan paroksismal. $^{3}$ Terdapat dua kategori dari kejang epilepsi yaitu kejang fokal (parsial) dan kejang umum. Kejang fokal terjadi karena adanya lesi pada satu bagian dari cerebral cortex, di mana pada kelainan ini dapat disertai kehilangan kesadaran. Pada kejang umum, lesi mencakup area yang luas dari cerebral cortex dan biasanya mengenai kedua hemisfer cerebri. ${ }^{4}$

Epilepsi memiliki efek merugikan pada kesejahteraan sosial dan psikologis seseorang. Efek ini termasuk isolasi sosial, stigmatisasi, atau ketidakmampuan yang bisa menyebabkan pencapaian prestasi belajar yang rendah dan kesempatan kerja yang buruk. Stigma sangat memengaruhi penderita epilepsi. Beberapa aspek dari stigma yang berhubungan dengan epilepsi adalah takut kejang, cedera, kematian, malu, kehilangan pekerjaan, kesempatan pendidikan, atau tidak diizinkan menikah. Banyak ahli kesehatan yang sering tidak mengetahui tentang epilepsi dari penyebabnya, diagnosis, pengobatan, aspek psikososial dan penyakit mental dalam hal stigma tersebut. ${ }^{5}$

Epilepsi dapat ditemukan pada semua usia dan dapat menyebabkan mortalitas. ${ }^{6}$ Pada beberapa orang yang memiliki epilepsi, risiko Sudden Unexpected Death in Epilepsy (SUDEP) adalah masalah penting. SUDEP mengacu pada kematian orang dengan epilepsi yang tidak disebabkan oleh cedera, tenggelam, atau penyebab lain. Studi menunjukkan bahwa setiap tahun ada sekitar 1,16 kasus untuk setiap 1.000 orang dengan epilepsi, meskipun perkiraannya bervariasi. ${ }^{7}$ Para peneliti telah menemukan bahwa SUDEP jarang terjadi pada anak-anak yang lebih muda. Sebagian besar, kasus SUDEP terjadi selama atau segera setelah kejang. Anak-anak dengan epilepsi yang tidak terkontrol atau kejang yang sering, memiliki risiko tertinggi untuk terjadi SUDEP. Selain itu, ada dua faktor risiko lain, yaitu onset awal epilepsi dan gangguan perkembangan. ${ }^{8}$

Berdasarkan data dari Epilepsy Foundation, jumlah penderita epilepsi di dunia saat ini mencapai 65 juta orang. Jumlah orang yang menderita epilepsi di United States of America (USA) adalah 3,4 juta dan kasus epilepsi semakin bertambah sebanyak 150.000 orang setiap tahun. ${ }^{9}$ Kejadian epilepsi tergolong masih cukup tinggi. Insiden epilepsi diperkirakan lebih banyak di negara berkembang daripada negara maju. ${ }^{10}$ Penderita epilepsi di negara Asia Tenggara, prevalensi yang didapatkan di Thailand sebesar 7,2 per 1.000 anak sekolah, sedangkan di Singapura didapatkan prevalensi sebesar 3,5 per 1.000 anak sekolah. $^{3}$

Dari berbagai macam hasil studi di Indonesia pada tahun 2011, diperkirakan prevalensi epilepsi berkisar antara 0,5\% sampai $4 \%$, dengan rata-rata prevalensi epilepsi 8,2 per 1.000 penduduk. Prevalensi epilepsi pada bayi dan anak-anak cukup tinggi, namun menurun pada dewasa muda dan 
pertengahan, kemudian meningkat kembali pada kelompok usia lanjut. ${ }^{11}$

Selama periode tahun 2013, jumlah kasus baru epilepsi anak di RSUD Dr. Soetomo Surabaya 103 kasus. Kasus terbanyak terjadi pada usia pasien 1-5 tahun $45,63 \%$ dan jenis kelamin laki-laki $71,84 \%$. Pada penelusuran riwayat pasien didapatkan $93,2 \%$ tidak memiliki riwayat keluarga kejang ataupun epilepsi. Pada tipe kejang menurut ILAE didapatkan 55,3\% generalized seizure, 37,9\% focal seizure, dan 6,8\% unknown. Pada hasil pemeriksaan EEG abnormal didapatkan $72,8 \%$. Pengobatan dengan asam valproat $89,3 \% .{ }^{10}$ Selama periode tahun 2017 , jumlah kasus epilepsi anak di RSUP Dr. M. Djamil Padang 1081 kasus pada rawat jalan dan satu kasus pada rawat inap.

\section{Metode Penelitian}

Ruang lingkup penelitian ini adalah bidang Ilmu Kesehatan Anak. Penelitian ini dilakukan mulai dari bulan April 2019 Januari 2020 di bagian bangsal anak RSUP. Dr. M. Djamil Padang. Jenis penelitian yang digunakan dalam penelitian ini adalah penelitian yang bersifat deskriptif. Rancangan penelitian yang digunakan dalam penelitian ini adalah penelitian cross sectional. $^{12}$

\section{A. Cara Pengumpulan Data}

Dalam penelitian ini, bahan yang digunakan dalam pengumpulan data yaitu dengan menggunakan data rekam medis. Alat yang digunakan dalam pengumpulan data yaitu dengan program SPSS yang digunakan untuk pengolahan data dan alat tulis yang digunakan untuk mencatat data yang dibutuhkan. Jenis data yang digunakan pada penelitian ini adalah data sekunder dimana data diperoleh dari catatan rekam medis pasien epilepsi di bangsal anak RSUP Dr. M. Djamil Padang tahun 2018.

\section{B. Analisis Data}

Analisis data dalam penelitian ini adalah univariat. Tujuan analisis univariat yaitu untuk menjelaskan atau mendeskripsikan karakteristik setiap variabel penelitian. Hasil penelitian ini berupa perhitungan proporsi dari variabel yang disajikan dalam bentuk tabel.

\section{Pengolahan Data}

1. Editing (pemeriksaan data)

2. Coding (memberikan tanda kode)

3. Entry (memasukkan data)

4. Tabulating (pembuatan tabel data)

\section{Hasil Penelitian}

Penelitian ini bertujuan untuk mengetahui karakteristik penderita epilepsi di bangsal anak RSUP Dr. M. Djamil Padang tahun 2018 yang dilakukan pada 65 sampel penelitian yang telah memenuhi kriteria inklusi dan eksklusi. Berdasarkan hasil pengumpulan dan analisa terhadap data yang telah didapat, maka hasil penelitian dapat disimpulkan dalam paparan di bawah ini:

\section{A. Usia}

Hasil penelitian didapatkan distribusi frekuensi pasien menurut usia pada penderita epilepsi di bangsal anak RSUP Dr. M. Djamil Padang tahun 2018 dapat dilihat pada tabel 1.

Tabel 1. Distribusi Frekuensi Pasien Menurut Usia Pada PENDERIta EPILEPSI di Bangsal ANaK RSUP. DR. M. DJAMIL PADANG TAHUN 2018

\begin{tabular}{ccc}
\hline \multicolumn{1}{c}{ Usia } & $\boldsymbol{N}$ & $\boldsymbol{\%}$ \\
\hline 0-5 tahun & 37 & 56,9 \\
6-11 tahun & 19 & 29,2 \\
12-16 tahun & 9 & 13,8 \\
\hline \multicolumn{1}{c}{ Total } & $\mathbf{6 5}$ & $\mathbf{1 0 0 , 0}$ \\
\hline
\end{tabular}

Berdasarkan tabel 1 didapatkan dari 65 sampel penderita epilepsi tertinggi pada usia $0-5$ tahun sebanyak 37 orang $(56,9 \%)$. 


\section{B. Jenis Kelamin}

Hasil penelitian didapatkan distribusi frekuensi pasien menurut jenis kelamin pada penderita epilepsi di bangsal anak RSUP Dr. M. Djamil Padang tahun 2018 dapat dilihat pada tabel 2.

Tabel 2. Distribusi frekuensi Pasien Menurut JENIS KELAMIN PADA PENDERITA EPILEPSI DI Bangsal ANAK RSUP. DR. M. DJAMIL PADANG TAHUN 2018

\begin{tabular}{llll}
\hline Jenis Kelamin & & $\boldsymbol{F}$ & $\boldsymbol{\%}$ \\
\hline Laki-laki & 39 & 60 \\
Perempuan & 26 & 40 \\
\hline Total & 65 & 100 \\
\hline
\end{tabular}

Berdasarkan tabel 2 didapatkan dari 65 sampel penderita epilepsi diperoleh jenis kelamin paling banyak adalah laki-laki sebanyak 39 orang (60\%).

\section{Riwayat Epilepsi Dalam Keluarga}

Hasil penelitian didapatkan distribusi frekuensi pasien menurut riwayat epeilepsi dalam keluarga pada penderita epilepsi di bangsal anak RSUP Dr. M. Djamil Padang tahun 2018 dapat dilihat pada tabel 3.

Tabel 3. Distribusi Frekuensi Pasien Menurut RIWAYAT EPILEPSI DALAM KELUARGA PADA PENDERITA EPILEPSI DI BANGSAL ANAK RSUP. DR. M. DJAMIL PADANg TAhun 2018

\begin{tabular}{lcc}
\hline $\begin{array}{l}\text { Riwayat epilepsi } \\
\text { keluarga }\end{array}$ & $\boldsymbol{N}$ & $\boldsymbol{\%}$ \\
\hline Ada & 3 & 4,6 \\
Tidak ada & 62 & 95,4 \\
\hline Total & 65 & 100,0 \\
\hline
\end{tabular}

Berdasarkan tabel 3 didapatkan dari 65 sampel penderita epilepsi diperoleh sebanyak 62 orang $(95,4 \%)$ tidak memiliki riwayat epilepsi keluarga.

\section{Gambaran EEG (Electroencephalography)}

Hasil penelitian didapatkan distribusi frekuensi pasien menurut gambaran EEG pada penderita epilepsi di bangsal anak
RSUP Dr. M. Djamil Padang tahun 2018 dapat dilihat pada tabel 4 .

Tabel 4. Distribusi Pasien Menurut Gambaran EEG PADA PENDERITA EPILEPSI DI BANGSAL ANAK RSUP. DR. M. DJAMIL PADANG TAHUN 2018

\begin{tabular}{lcc}
\hline Gambaran EEG & $\boldsymbol{N}$ & \% \\
\hline Gel. Lambat & 3 & 4,6 \\
Gel. Paku & 3 & 4,6 \\
Gel. Paku Ombak & 6 & 9,2 \\
Gel. Tajam & 23 & 35,4 \\
Gel. Tajam dan Paku & 30 & 46,2 \\
\hline Total & 65 & 100,0 \\
\hline
\end{tabular}

Berdasarkan tabel 4 didapatkan dari 65 sampel penderita epilepsi diperoleh sebanyak 30 orang $(46,2 \%)$ memiliki gambaran EEG pada gelombang tajam dan paku.

\section{E. Klasifikasi ILAE}

Hasil penelitian didapatkan distribusi frekuensi pasien menurut klasifikasi ILAE pada penderita epilepsi di bangsal anak RSUP Dr. M. Djamil Padang tahun 2018 dapat dilihat pada tabel 5 .

Tabel 5. Distribusi Pasien Menurut Tipe KEJANG (KLASIFIKASI ILAE 2017) PADA PENDERITA EPILEPSI DI BANGSAL ANAK RSUP. DR. M. DJAMIL PADANG TAHUN 2018

\begin{tabular}{lcc}
\hline Tipe kejang & $\boldsymbol{N}$ & $\mathbf{\%}$ \\
\hline Generalized & 57 & 87,7 \\
Focal & 5 & 7,7 \\
Unclassified & 3 & 4,6 \\
\hline Total & 65 & 100,0 \\
\hline
\end{tabular}

Berdasarkan tabel 5 didapatkan dari 65 sampel penderita epilepsi diperoleh sebanyak 57 orang $(87,7 \%)$ memiliki tipe kejang generalized.

\section{F. Penatalaksanaan}

Hasil penelitian didapatkan distribusi frekuensi pasien menurut penatalaksanaan pada penderita epilepsi di bangsal anak RSUP Dr. M. Djamil Padang tahun 2018 dapat dilihat pada tabel 6 . 
Tabel 6. Distribusi Pasien Menurut PenatalaksanaAn Pada Penderita EPILePSi di Bangsal Anak RSUP. Dr. M. DJamil Padang TAHUN 2018

\begin{tabular}{lcc}
\hline Penatalaksanaan & $\boldsymbol{N}$ & \% \\
\hline Tunggal & & \\
$\quad$ Asam Valproat & 32 & 49,2 \\
$\quad$ Luminal & 21 & 32,3 \\
Kombinasi & & \\
$\quad$ Asam Valproat + Luminal & 10 & 15,4 \\
$\quad$ Fenitoin + Luminal & 2 & 3,1 \\
\hline Total & 65 & 100,0 \\
\hline
\end{tabular}

Berdasarkan tabel 6 didapatkan dari 65 sampel penderita epilepsi diperoleh sebanyak 32 orang $(49,2 \%)$ memakai Asam Valproat sebagai salah satu penatalaksanaan epilepsi.

\section{Pembahasan}

\section{A. Distribusi Usia pada Penderita Epilepsi}

Penelitian yang dilakukan terhadap 65 sampel yang tercatat pada rekam medik pasien penderita epilepsi di bangsal anak RSUP Dr. M. Djamil Padang tahun 2018, didapatkan bahwa frekuensi tertinggi pada usia 0-5 tahun. Pada hasil penelitian, frekuensi pasien penderita epilepsi menunjukkan angka tertinggi pada usia 0-5 tahun sebanyak 37 orang $(56,9 \%)$ dari seluruh sampel dan diikuti usia 6-11 tahun sebanyak 19 orang $(29,2 \%)$.

Hasil penelitian ini sesuai dengan penelitian yang dilakukan oleh Jamalludin pada tahun 2014 di RSUP Haji Adam Malik, menunjukan hasil kasus penderita epilepsi terbanyak pada usia 4 bulan -5 tahun yaitu 17 orang $(42,5 \%),{ }^{13}$ dan hasil yang sama ditemukan pada hasil penelitian Andrianti pada tahun 2016 di RSUD Dr. Soetomo didapatkan penderita epilepsi terbanyak pada usia 1-5 tahun yaitu 47 orang $(45,6 \%) .{ }^{10}$

Hal ini sesuai dengan insiden epilepsi yang lebih tinggi terdapat pada bayi dan anakanak, menurun pada dewasa muda dan pertengahan, kemudian meningkat kembali pada kelompok usia lanjut. ${ }^{11}$ Telah diketahui bahwa di awal kehidupan, otak lebih rentan mengalami kejang dan kejang di otak yang belum matang cenderung tergantung pada mekanisme yang berbeda daripada orang dewasa. Epilepsi pada anak usia dini seringkali sulit diobati. Ini mungkin tergantung pada fisiologis yang belum matang dalam homeostasis ion dan karakteristik perkembangan lainnya. Disfungsi otak neonatal dan ekspresi perilakunya mungkin berasal dari periode antepartum. Kejang pada kehidupan awal memang menyebabkan perubahan morfologis yang jauh lebih kronis di bagian hipokampus daripada kejang pada epilepsi saat dewasa pada bagian lobus temporal otak. Namun, kejang pada kehidupan awal yang berulang dapat mengakibatkan kelainan perilaku permanen dan meningkatkan epileptogenisitas. ${ }^{14}$

Pada epilepsi, banyak faktor yang dapat mencederai sel-sel, saraf otak atau lintasan komunikasi antar sel otak. Gangguan ini dapat menyebabkan terjadinya gangguan fisiologis, biokimia, anatomi dengan manifestasi baik lokal maupun general. Gangguan ini tidak terbatas aktifitas motorik yang terlihat oleh mata, tetapi juga oleh aktifitas lain misalnya emosi, pikiran dan persepsi. Berdasarkan teori, bahwa faktorfaktor yang di teliti dapat menjadi faktor risiko terjadinya epilepsi, tetapi berdasarkan hasil penelitian Lestari pada tahun 2012-2014 di RSUD Dr. H. Abdul Moeloek Bandar Lampung, diketahui bahwa pasien epilepsi dengan riwayat kejang demam paling banyak dijumpai dibandingkan dengan faktor-faktor lainnya yang memiliki persentase lebih kecil, dimana pada penelitian ini terdapat 21 responden $(67,7 \%)$ yang memiliki riwayat kejang demam. ${ }^{15}$

Pada bayi, bagian otak yang sudah berkembang adalah hippocampus, didaerah tersebut lesi yang diakibatkan oleh kejang demam pada usia kurang dari 1 tahun dapat menjadi fokus epileptogenik. Angka kejadian 
epilepsi pada penderita kejang kira-kira dua hingga tiga kali lebih banyak terjadi pada kejang yang berulang. Kejang yang terjadi lebih dari 15 menit dapat menyebabkan kerusakan neuron secara menetap, sementara kejang demam yang terjadi lebih dari 30 menit dapat menyebabkan kerusakan pada DNA (Deoxyribose Nucleic Acid) dan protein otak sehingga dapat menimbulkan jaringan parut, hal ini mengakibatkan terganggunya mekanisme homeostatis otak dengan menurunnya proses inhibisi atau penghambat listrik dan meningkatkan proses eksitasi atau cetusan listrik. Jika mekanisme yang tidak seimbang ini terjadi secara berkepanjangan, maka dapat mengakibatkan sklerosis pada jaringan otak dan dengan demikian terbentuk fokus epilepsi. ${ }^{15}$

\section{B. Distribusi Jenis Kelamin pada Penderita Epilepsi}

Penelitian yang dilakukan terhadap 65 sampel yang tercatat pada rekam medik pasien penderita epilepsi di bangsal anak RSUP Dr. M. Djamil Padang tahun 2018, didapatkan bahwa jenis kelamin yang paling banyak menderita epilepsi adalah laki-laki. Pada hasil penelitian didapatkan sebanyak 39 orang $(60 \%)$ laki-laki sedangkan perempuan sebanyak 26 orang $(40 \%)$.

Hasil penelitian ini sesuai dengan penelitian yang dilakukan oleh Suwarba pada tahun 2011 di RSUP Sanglah, Denpasar, Bali yang menunjukan kasus penderita epilepsi terdapat pada jenis kelamin laki-laki sebanyak 157 orang $(56,9 \%) .{ }^{16}$ Penelitian ini juga sejalan dengan penelitian Tjandrajani, dkk pada tahun 2012 di RS Anak dan Bunda Harapan Kita yang mendapatkan hasil penelitian jenis kelamin laki-laki sebanyak 76 orang $(53,9 \%){ }^{17}$

Menurut Singh dan Trevick pada tahun 2016, secara genetik dan fisiologis aktivitas otak dan transfer impuls antar sinaps pada lakilaki lebih cepat dibanding perempuan. Itu yang menyebabkan seorang laki-laki lebih beresiko terkena epilepsi dibanding
perempuan.

\section{Distribusi Riwayat Epilepsi dalam Keluarga pada Penderita Epilepsi}

Penelitian yang dilakukan terhadap 65 sampel yang tercatat pada rekam medik pasien penderita epilepsi di bangsal anak RSUP Dr. M. Djamil Padang tahun 2018, didapatkan bahwa anak yang menderita epilepsi tidak memiliki riwayat epilepsi dalam keluarga. Didapatkan hasil penelitian sebanyak 62 orang $(95,4 \%)$ tidak memiliki riwayat epilepsi dalam keluarga dan 3 orang $(4,6 \%)$ memiliki riwayat epilepsi dalam keluarga.

Hasil penelitian ini sesuai dengan penelitian yang dilakukan oleh Suwarba pada tahun 2011 di RSUP Sanglah, Denpasar, Bali yang menunjukan bahwa kasus penderita epilepsi tidak memiliki riwayat epilepsi dalam keluarga sebanyak 240 orang $(87,0 \%) .^{16}$ Hasil penelitian ini juga sejalan dengan penelitian Triono, dkk pada tahun 2019 yang menyatakan bahwa sebanyak 20 orang $(35,1 \%)$ tidak memiliki riwayat epilepsi dalam keluarga. ${ }^{19}$

Menurut teori Andrianti pada tahun 2016, riwayat epilepsi dalam keluarga bukan penyebab langsung terjadinya epilepsi melainkan hanya sebagai faktor risiko. Kelainan perinatal, seperti bayi biru, tidak bernafas spontan, tidak langsung menangis, serta beberapa kelainan pada ketuban ibu juga dapat menjadi faktor risiko terjadinya epilepsi pada anak. ${ }^{10}$

\section{Distribusi Gambaran EEG (Electroencephalography) pada Penderita Epilepsi}

Penelitian yang dilakukan terhadap 65 sampel yang tercatat pada rekam medik pasien penderita epilepsi di bangsal anak RSUP Dr. M. Djamil Padang tahun 2018, data yang tertinggi terdapat pada gelombang tajam dan paku. Hasil penelitian diperoleh 
sebanyak 30 orang $(46,2 \%)$ memiliki gambaran EEG pada gelombang sharp wave dan spike dan diikuti dengan gelombang tajam sebanyak 23 orang $(35,4 \%)$.

Hasil penelitian ini sesuai dengan penelitian yang dilakukan oleh Ponnusamy pada tahun 2017 di RSUP Haji Adam Malik menunjukan bahwa terdapat sebanyak 44 orang (36\%) yang memiliki gambaran EEG gelombang tajam dan paku. ${ }^{14}$ Hasil ini juga sejalan dengan penelitian Nasution pada tahun 2018 yang memiliki gambaran EEG gelombang tajam dan paku sebanyak 58 orang $(50,4 \%){ }^{21}$

Menurut WHO pada tahun 2012, epilepsi merupakan gangguan otak kronik yang terjadi akibat adanya ketidaknormalan kerja sementara sebagian atau seluruh jaringan otak karena cetusan listrik pada neuron yang dapat menunjukan gelombang abnormal dalam pemeriksaan EEG. Hal ini sesuai dengan sumber yang mengatakan bahwa gelombang abnormal sering ditemukan pada pemeriksaan EEG pasien yang menderita epilepsi. $^{20}$

Gelombang epileptiform lebih sering ditemukan pada sindrom epilepsi atau tipe kejang tertentu. Lokasi dari daerah epileptiform juga dapat menentukan terjadinya gelombang epileptiform. ${ }^{22}$ Gambaran gelombang epileptiform diakibatkan oleh beberapa faktor risiko, seperti usia, jenis epilepsi dan tipe kejang. Dalam studi sebelumnya dari subyek dengan insiden kejang tanpa provokasi, hasil kelainan epileptiformis pada EEG pertama hanya $32 \%-59 \%$ pada anak-anak dan $12 \%$ $44 \%$ pada orang dewasa. Hal ini berlaku untuk kelompok usia 1- 19 tahun dibandingkan dengan orang dewasa setelah menyesuaikan frekuensi kejang yang menunjukkan bahwa pemeriksaan EEG paling berguna pada anak-anak dan remaja. Baldin, dkk pada tahun 2014 telah melakukan sebuah penelitian dan menemukan bahwa tidak ada proporsi yang berbeda antara epilepsi idiopatik dengan simptomatik terhadap kejadian epileptiform. Pengaruh tipe kejang terhadap kejadian gelombang epileptiform juga pernah dilakukan oleh Baldin, dkk pada tahun 2014 dengan hasil proporsi pada kejang umum justru lebih banyak daripada kejang fokal. ${ }^{22,23}$

\section{E. Distribusi Tipe Kejang (Klasifikasi ILAE 2017) pada Penderita Epilepsi}

Penelitian yang dilakukan terhadap 65 sampel yang tercatat pada rekam medik pasien penderita epilepsi di bangsal anak RSUP Dr. M. Djamil Padang tahun 2018, data yang tertinggi terdapat pada tipe kejang generalized. Pada hasil penelitian diperoleh sebanyak 57 orang $(87,7 \%)$ memiliki tipe kejang generalized dan diikuti dengan tipe kejang focal sebanyak 5 orang $(7,7 \%)$.

Hasil penelitian ini sesuai dengan penelitian yang dilakukan oleh Jamalludin pada tahun 2014 di RSUP Haji Adam Malik yang memiliki tipe kejang umum sebanyak 33 orang $(82,5 \%) .{ }^{13}$ Penelitian ini juga sejalan dengan penelitian Lavina, dkk pada tahun 2015 di RS Dr. Cipto Mangunkusumo, Jakarta menunjukan bahwa tipe kejang yang terbanyak yaitu tipe kejang umum sebanyak 21 orang $(70 \%){ }^{24}$

Hasil ini sesuai dengan teori pada penelitian Ponnusamy, yang mengatakan epilepsi serangan umum lebih banyak dibandingkan dengan serangan fokal. Pasien penderita epilepsi dengan serangan umum banyak terjadi pada anak-anak dan remaja, sedangkan serangan fokal banyak terjadi pada usia dewasa. Epilepsi fokal sering terjadi pada dewasa bisa karena stroke, trauma kepala, post operasi gangguan vaskular dan Alzheimer. ${ }^{20}$

\section{F. Distribusi Penatalaksanaan pada Penderita Epilepsi}

Penelitian yang dilakukan terhadap 65 sampel yang tercatat pada rekam medik pasien penderita epilepsi di bangsal anak 
RSUP Dr. M. Djamil Padang tahun 2018, data terbanyak terdapat pada penggunaan obat asam valproat. Hasil penelitian diperoleh sebanyak 32 orang $(49,2 \%)$ memakai asam valproat sebagai salah satu penatalaksanaan epilepsi dan diikuti dengan pengobatan dengan Luminal sebanyak 21 orang $(32,3 \%)$.

Hasil penelitian ini sesuai dengan penelitian yang dilakukan oleh Umma pada tahun 2014 menunjukan bahwa obat yang digunakan untuk penatalaksanaan penderita epilepsi yaitu asam valproat sebanyak 13 orang $(54,2 \%) .{ }^{25}$ Penelitian ini juga sejalan dengan penelitian Andrianti pada tahun 2016 di RSUD Dr. Soetomo yang menunjukan bahwa obat yang digunakan terbanyak yaitu asam valproat sebanyak 92 orang $(89,3 \%){ }^{10}$

Asam valproat dan Luminal (Fenobarbital) merupakan OAE lini pertama yang digunakan dalam penatalaksanaan epilepsi yang gunanya untuk menjaga keseimbangan antara eksitasi dan inhibisi potensi post sinaptik. $^{25}$ Beberapa penelitian memperlihatkan bahwa terjadi peningkatan kadar GABA di otak setelah pemberian asam valproat, meskipun mekanisme peningkatan ini masih belum diketahui dengan jelas. Asam valproat juga dapat memfasilitasi Asam glutamat dekarboksilasi, suatu enzim yang berperan dalam sintesis GABA. Efek inhibitorik pada pengangkut Transporter GABA (GAT-1) juga mungkin berperan. Pada konsentrasi yang sangat tinggi, asam valproat menghambat GABA transminase di otak sehingga penguraian GABA terhambat. Asam valproat adalah inhibitor kuat Histone Deacetylase dan melalui mekanisme ini dapat mengubah transkripsi banyak gen. ${ }^{26,27}$

\section{Penutup}

\section{A. Kesimpulan}

Berdasarkan hasil penelitian mengenai karakteristik penderita epilepsi di bangsal anak RSUP Dr. M. Djamil Padang tahun 2018, maka dapat disimpulkan bahwa:
1. Usia pada penderita epilepsi di bangsal anak RSUP Dr. M. Djamil Padang tahun 2018 paling banyak pada usia 0-5 tahun sebanyak 37 orang $(56,9 \%)$.

2. Jenis kelamin pada penderita epilepsi di bangsal anak RSUP Dr. M. Djamil Padang tahun 2018 paling banyak adalah laki-laki sebanyak 39 orang $(60 \%)$.

3. Riwayat epilepsi keluarga pada penderita epilepsi di bangsal anak RSUP Dr. M. Djamil Padang tahun 2018 paling banyak yaitu tidak memilki riwayat epilepsi keluarga sebanyak 62 orang $(95,4 \%)$.

4. Gambaran EEG pada penderita epilepsi di bangsal anak RSUP Dr. M. Djamil Padang tahun 2018 paling banyak yaitu pada gelombang tajam dan paku sebanyak 30 orang $(46,2 \%)$.

5. Klasifikasi ILAE pada penderita epilepsi di bangsal anak RSUP Dr. M. Djamil Padang tahun 2018 paling banyak adalah tipe kejang generalized sebanyak 57 orang $(87,7 \%)$.

6. Penatalaksanaan pada penderita epilepsi di bangsal anak RSUP Dr. M. Djamil Padang tahun 2018 paling banyak yaitu asam valproat sebanyak 32 orang $(49,2 \%)$.

\section{B. Saran}

Berdasarkan kesimpulan hasil penelitian yang dilakukan di RSUP Dr. M. Djamil Padang tahun 2018, maka saran yang bisa diberikan adalah:

\section{Bagi Institusi}

Diharapkan kepada bagian rekam medis di RSUP Dr. M. Djamil Padang dapat lebih ditingkatkan lagi kualitas data rekam medis baik dari kejelasan maupun kelengkapan datanya.

\section{Bagi Peneliti Selanjutnya}

Diharapkan peneliti selanjutnya dapat melakukan penelitain lebih lanjut dan lebih lengkap dengan variabel yang berbeda serta data yang lebih banyak dengan tempat yang berbeda mengenai karakteristik epilepsi pada anak. 


\section{Daftar Pustaka}

[1] Fisher RS. A practical clinical definition of epilepsy. ILAE Official Report. 2014:477.

[2] Who.int. Epilepsy. 2019. [online] Available at: https://www.who.int/en/news-room/factsheets/detail/epilepsy [Accessed 31 Aug. 2019].

[3] Yolanda NGA, Sareharto TP, Istiadi H. Jurnal Kedokteran Diponegoro [Internet]. Ejournal3.undip.ac.id. 2019 [cited 25 August 2019]. Available from: http://ejournal3.undip.ac.id/index.php/medico

[4] Setiaji A. Pengaruh Penyuluhan Tentang Penyakit Epilepsi Anak Terhadap Pengetahuan Masyarakat Umum [Skripsi]. Semarang: Fakultas Kedokteran Universitas Diponegoro; 2014.

[5] Wulan Maryanti N. Epilepsi dan Budaya. Buletin Psikologi. 2016;24(1):29.

[6] Ikawati Z. Farmakoterapi Penyakit Sistem Saraf Pusat. Yogyakarta: Bursa Ilmu Karangkajen. 2011:85-102.

[7] Sudden Unexpected Death in Epilepsy (SUDEP) | CDC [Internet]. Cdc.gov. 2019 [cited 27 August 2019]. Available from: https://www.cdc.gov/epilepsy/about/sudep/index. $\underline{\mathrm{htm}}$

[8] SUDEP Information for Parents of Children with Epilepsy | CDC [Internet]. Cdc.gov. 2019 [cited 27 August 2019]. Available from: https://www.cdc.gov/epilepsy/about/sudep/parent $\underline{\text { s.htm }}$

[9] Epilepsy. Epilepsy Foundation. 2017. [Online]. [cited 19 April 2019]. Available from: http://www.epilepsy.com/learn/about-epilepsybasics

[10] Andrianti PT, Gunawan PI, dan Hoesin F. Profil Epilepsi Anak dan Keberhasilan Pengobatannya di RSUD Dr. Soetomo Tahun 2013. Sari Pediatri. 2016;18(1):34.

[11] Rajandran M. Gambaran Karakteristik Pada Pasien Epilepsi di RSUP Haji Adam Malik Pada tahun 2016 [Skripsi]. Medan: Program Studi Pendidikan Dokter Fakultas Kedokteran Universitas Sumatera Utara; 2017

[12] Sopiyudin M. Langkah - Langkah Membuat Proposal Penelitian Bidang Kedokteran dan Kesehatan Seri 3 Edisi 2. Jakarta: Sagung Seto; 2012.

[13] Jamalludin SNF. Prevalensi Dan Karakteristik Epilepsi Pada Anak Di RSUD Haji Adam Malik Periode 2011-2012. [Skripsi]. Medan: Fakultas Kedokteran Universitas Sumatera Utara; 2014.

[14] Wahab A. Difficulties in Treatment and Management of Epilepsy and Challenges in New Drug Develpoment. Pharmaceuticals. 2010;3(7):2090-110.
[15] Lestari SMP, Mudapati A. Faktor-Faktor Yang Terdapat Pada Kejadian Epilepsi Anak Usia $\leq 5$ Tahun Di Rsud Dr. H. Abdul Moeloek Bandar Lampung Tahun 2012-2014 [Internet]. Ejurnalmalahayati.ac.id. 2014 [cited 2 December 2019]. Available from: http://www.ejurnalmalahayati.ac.id/index.php/ke sehatan/article/viewFile/671/613

[16] Suwarba IGNM. Insiden dan Karakteristik Klinis Epilepsi Pada Anak. Sari Pediatri. 2011;13(2):125.

[17] Tjandrajani A, Widjaja JA, Dewanti A dan Burhany AA. Karakteristik kasus epilepsi di rumah sakit anak dan bunda harapan kita pada tahun 2008-2010. Sari Pediatri. 2012;14(3):144.

[18] Singh A, Trevick S. The Epidemiology of Global Epilepsy. Neurologic Clinics. 2016;34(4):837-47.

[19] Triono A, Herini ES, Mangunatmadja I. Luaran Klinis Anak Dengan Epilepsi Yang Mengalami Relaps Setelah Penghentian Obat Antiepilepsi. Sari Pediatri. 2019;20(6):338.

[20] Ponnusamy S. Gambaran Elektroensefalografi Pada Pasien Epilepsi di Rumah Sakit Umum Pusat Haji Adam Malik September 2016-September 2017 [Skripsi]. Medan: Program Studi Pendidikan Dokter Fakultas Kedokteran Universitas Sumatera Utara; 2017

[21] Nasution IGA. Gambaran Elektroensefalografi pada Penderita Kelainan Neurologi di RSUP Haji Adam Malik Medan Tahun 2016-2017 [Skripsi]. Medan: Program Studi Pendidikan Dokter Fakultas Kedokteran Universitas Sumatera Utara; 2018

[22] Tartila. Gambaran Gelombang Epileptiform Pada EEG Anak dengan Epilepsi: Kajian Pada Faktor-faktor yang Memengaruhi [Tesis]. Jakarta: Fakultas Kedokteran Universitas Indonesia Program Pendidikan Dokter Spesialis Ilmu Kesehatan Anak; 2015.

[23] Baldin E, Hauser W, Buchhalter J, Hesdorffer D, Ottman R. Yield of epileptiform electroencephalogram abnormalities in incident unprovoked seizures: A population-based study. Epilepsia. 2014;55(9):1389-98.

[24] Lavina A, Widodo DP, Nurdadi S, Tridjaja B. Faktor-faktor yang Memengaruhi Gangguan Perilaku Pada Anak Epilepsi. Sari Pediatri. 2015;16(6):411.

[25] Umma HA. Hubungan Efek Terapi Fenobarbital Terhadap Gambaran Elektrokardiogram Pada Anak Dengan Epilepsi [Tesis]. Surakarta: Program Pascasarjana Universitas Sebelas Maret; 2014. 3 